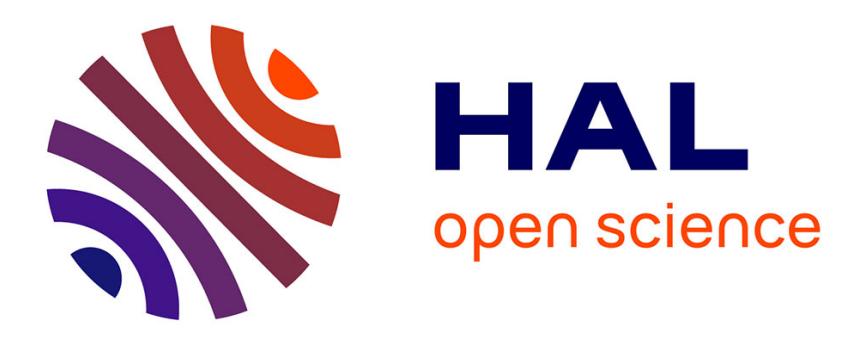

\title{
11 Sargonic Tablets in the Süleymaniah Museum
}

\author{
Ari Kamil, Camille Lecompte
}

\section{To cite this version:}

Ari Kamil, Camille Lecompte. 11 Sargonic Tablets in the Süleymaniah Museum. Revue d'Assyriologie et d'Archéologie orientale, 2021, 115 (1-12). hal-03439482

\section{HAL Id: hal-03439482 \\ https://hal.science/hal-03439482}

Submitted on 1 Dec 2021

HAL is a multi-disciplinary open access archive for the deposit and dissemination of scientific research documents, whether they are published or not. The documents may come from teaching and research institutions in France or abroad, or from public or private research centers.
L'archive ouverte pluridisciplinaire HAL, est destinée au dépôt et à la diffusion de documents scientifiques de niveau recherche, publiés ou non, émanant des établissements d'enseignement et de recherche français ou étrangers, des laboratoires publics ou privés. 


\section{SARGONIC TABLETS IN THE SÜLEYMANIAH MUSEUM}

BY

Ari KAMIL and Camille LECOMPTE

\section{INTRODUCTION}

The Museum of Süleymaniah, Kurdistan, Iraq, houses among its collection of cuneiform texts eleven hitherto unpublished tablets and fragments dating back to the Sargonic period. The tablets were purchased in 2009 and included in its catalogue in 2013. We would like to thank the trustees of the Süleymaniah Museum for their permission to publish the documents here. ${ }^{1}$

According to their data, most of these tablets seem to come from Adab:

- the provenance of tablets $1,3,5,6,7,8,9$ and 10 is secured by diverse concordances with the previously published documents from Adab

- tablets 4 and 11 most probably come from Adab

- a doubt arises in the case of tablet 2, which might belong to the group of legal documents from Isin but might also originate from Adab, or even from another city.

\section{EDITION OF THE TEXTS}

Text 1. SM.039816 (=T3816)

Date: Middle Sargonic. Month iii. ${ }^{2}$ Origin: Adab.

Dimensions $(\mathrm{h} \times \mathrm{w} \times \mathrm{t}): 50 \times 36 \times 15$

Content: distribution of loaves of bread.

Obverse

1. $\left.{ }^{\top} 20\right\urcorner$ ninda

2. $B e-l i_{2}-Q A R$

3. KU-lugal

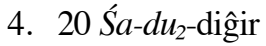

5. $\operatorname{lu}_{2} I b-n i-{ }^{\mathrm{d}} S u$ en

6. 20 Ama-bara 2 -ge-si

7. $20 \mathrm{Me}-$ Unug $^{\mathrm{ki}}$-si!(e)

8. $\mathrm{lu}_{2} \mathrm{ma}_{2}-\mathrm{u}_{11}$
Reverse

1. ${ }^{120 \mathrm{Il}_{2}}{ }^{\top}$

2. 10 En-ne $_{2}$

3. dub-sar

4. 10 Ur- ${ }^{\mathrm{d}}$ En-ki

5. [1] $\mathrm{u}_{2}$ En-bu-digigir blank line

6. [šu]-niĝen 2120 ninda $1 / 2$ sila $_{3}$

7. [iti] še-sa $\hat{g}_{-} \operatorname{sig}_{15}$-ga

"20 loaves of bread: Belī-QAR, the KU-lugal; 20 (loaves): Śadî-ilum, the man of Ibni-Su'en; 20 (loaves): Ama-baragesi; 20 (loaves): Me-Unugesi, the travelling merchant; 20 (loaves): Il; 10 (loaves): Enne, the scribe; 10 (loaves): Ur-Enki, the man of Enbu-ilī. Total: 120 loaves of bread (of) 1/2 sila. Month iii”.

1. We also thank Manuel Molina and Antoine Cavigneaux for their valuable suggestions and corrections, Emmert Clevenstine and Anne-Christine Parr for the correction of our English.

2. On the Adab calendar, see Maiocchi (2009: 11-12) and Molina (2014: 38-39). 


\section{Commentary}

Obv. 2-3. A few individuals bear the same name during the Sargonic period, cf. CUSAS 35, 288 rs. 1 from Adab. The interpretation of this name, and of the sign $\mathrm{GAR}_{3} / \mathrm{qar}$, used in several names of the type DN-qar, is uncertain, see Hilgert 2002: 332-332; Gelb 1957: 148 (KR?); Pagan 1998: 220-221, who appears to connect it with kr, "ram". It has been variously interpreted as a shortened form of qarradum or as waqar, see the bibliographical references in Hilgert 2002: $332 \mathrm{fn} .62 ;{ }^{3}$ the name may therefore be either Beli- $q a r(r a d)$ or Belī-(wa)qar. On the profession KU-lugal, see Molina 2014: 110.

Obv. 4-5. Both individuals occur in a text dealing with containers, CUSAS 20, 32, obv. 1-rs. 5: $S a-d u_{2} / \operatorname{lu}_{2} I b-n i$ - ${ }^{\mathrm{d}} S u^{\prime} e n$, the former being an abbreviation of $\hat{S} a$ - $d u_{2}$-diĝir. The personal name $S a-d u_{2}$-diĝir, also written $\hat{S} a-d u_{2}-i_{3}$-lum (cf. MAD 5, 38. obv. ii. 3), is attested elsewhere (Gelb 1957: 264, śa-du being interpreted as šadûm), notably in Gasur (see HSS 10, p. xxxvi for the references).

Obv. 6. The same name occurs for instance in (Pre)-Sargonic texts from Nippur, OSP 1, 66. obv. 4 and OSP 1, 114. obv. 2. Obv. 7. Compare with the name mentioned in several Old Akkadian documents from Adab, Me-Unugki-ge-si: CUSAS 23, 82. obv. i. 2 and Bartash (2017: 509). It could also be interpreted here as Me-Unugki-e-<si $>$.

Obv. 8. For a reading $\mathrm{u}_{11}$ of $\mathrm{HU}$, see Molina (2014: 76 and 121) with bibliography. It is therefore identical with the profession mentioned in the $\mathrm{Lu}_{2}$ list, $\mathrm{lu}_{2} \mathrm{ma}_{2}-\mathrm{u}_{5}: \check{s} a_{2} r u-k u-b i_{3}$ (CAD R, p. 409).

Text 2. SM.039833 (= T3833)

Date: Middle Sargonic. Origin: Adab or Isin (?).

Dimensions: $84 \times 44 \times 22$

Content: triple oath concerning a dusu 2 -equid.

Obverse

1. 1 dusu $_{2}$

2. $\mathrm{Lu}_{2}-\mathrm{gu}-\mathrm{la} \mathrm{za}^{?}$ ba-tum

3. $\mathrm{bi}_{2}-\mathrm{du}_{11}$

4. mu lugal al-pa

5. 1 Ur- ${ }^{\mathrm{d}}$ Ištaran

6. dumu Ur-lu 2

7. $1 \mathrm{Ab}-\mathrm{KID}$

8. dumu Lugal-ad-da

9. $1 \mathrm{E}_{2}$-nig $\hat{g}_{2}$ nu-kiri 6

10. $1 \mathrm{Sa} \hat{\mathrm{g}}-\mathrm{AB}$ dumu $\mathrm{Za}_{3}-\mathrm{mu}$

11. $1 I_{3}-l i_{2}-t a b_{x}(\mathrm{MIN})-b a$

12. aga $_{3}-$ us $_{2}$ lugal

blank line

13. $\mathrm{lu}_{2}$-ki-inim-me

14. $\mathrm{e}_{2} I s-t a_{2}-m a^{?}-l a_{2}{ }^{\underline{?}}{ }^{\mathrm{ki}}-\mathrm{me}$

edge lu $\mathrm{u}_{2} \mathrm{ki}$-inim-ma-me

“" 1 dusu 2 -equid: Lugula the reading (?) took it away' (alternative reading 1 dusu for four (shekels) took it away'): he (Zamu) declared; the oath by the name of the king was sworn. 'UrIštaran, son of Ur-lu; ' $\mathrm{Ab}-\mathrm{KID}$, son of Lugal-adda; 'Eniĝ, the gardener; ISaĝ-AB, son of Zamu; ${ }^{\mathrm{I}} I l \bar{\imath}$ tappê, the royal soldier: they are the witnesses, they are (in) the house of Istamala (?). For the second time, the oath by the name of the king was sworn: ${ }^{\mathrm{I} U r-s a}$, ${ }^{\mathrm{L}} \mathrm{Lu}-\mathrm{sa},{ }^{\mathrm{I}} \mathrm{Ur}$-sipada, ${ }^{\mathrm{I}} \mathrm{U}-\mathrm{AB}$ : (they are) the witnesses, they are in the house of Giri-ne (?). For the third time, Zamu swore by the name of the king: ILu-sa, the supervisor, IDayyānum, IDagula, ILugal-itida, (groom) of the donkeys (?): they are the witnesses".

\section{Commentary}

Although the text may originate from Adab, its content as well as the use of PA for $\mathrm{pa}_{3}$ point toward Isin. The prosopography does not provide enough evidence to determine its provenance but does show some connections with Adab. ${ }^{4}$

3. Compare with Maiocchi (2009: 18 and 250), who interprets $i_{3}$-lum-qar as Ilum-qar(rad).

4. Note that Ur-sa 6 occurs in several texts from Isin, such as CUSAS 26, 53. rs. 6. CUSAS 26, 54. obv. 2. Obv. 14. Compare also $\mathrm{E}_{2}$-ni $\hat{\mathrm{g}}_{2}$ (cf. Balke dubsar 1, p. 142) with $\mathrm{E}_{2}$-ğar-bi, cf. CUSAS 35, 348. obv. 3 from Adab, and BIN 8, 167, rs. 8 , from Isin (which also contains $\mathrm{Za}_{3}-\mathrm{mu}$ ).

\section{Reverse}

2. mu lugal al-pa

3. $1 \mathrm{Ur}(\mathrm{ma})-\mathrm{sa}_{6}$

4. $1 \mathrm{Lu}_{2}-\mathrm{Sa}_{6}$

1 Ur-sipa-da

r-AB

8. $\mathrm{e}_{2}$ Giri ${ }_{3}-\mathrm{ne}_{2} \mathrm{ki}_{\text {-ka-me }}$

9. a-ra 2 3-ka-ma

$\mathrm{Za}_{3}-\mathrm{mu}$

13. $1 \mathrm{Di}^{-k u_{5}}$

14. 1 Da-gu-la

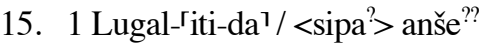




\section{ABSTRACT}

This paper aims to publish Sargonic tablets belonging to the Museum of Süleymaniah, Iraq. originating from Adab, are consistent with the bulk of administrative documents previously published in recent years. Another legal document, either from Adab or from Isin, features a rare example of a triple oath relating to a dusu ${ }_{2}$-equine.

\section{RÉSUMÉ}

Cet article présente la publication de tixtablettes d'époque sargonique du Musée de Süleymanieh en Irak. provenant d'Adab, sont des textes administratifs cohérents avec le reste de la documentation de ce site publiée récemment. Un document juridique, d'Adab ou d'Isin, comporte la mention d'un triple serment dans le cadre d'une affaire peu claire relative à un équidé dusu 2 .

Ari Kamil

Camille Lecompte

Salahaddin University

CNRS - UMR 7041 